\section{Ownership and disuse of bed nets in Kenyan children under five years of age}

\author{
Kacey C. Ernst, ${ }^{1}$ Mona Arora, ${ }^{2}$ \\ Stephen Munga ${ }^{3}$ \\ 1 Division of Epidemiology and \\ Biostatistics, School of Public Health, \\ University of Arizona, Tucson, AZ, USA; \\ 2Department of Geography, University of \\ Arizona, Tucson, AZ, USA; ${ }^{3}$ Kenyan \\ Medical Research Institute, Kisumu, \\ Kenya
}

\section{Abstract}

Recent campaigns to increase the percentage of households owning a bed net have been very successful yet there remains a subset of the population who do not sleep under bed nets. We used data from the 2008 Kenya Demographic and Health Survey (KDHS) to compare children under the age of five years of age who slept under any bed net to children sleeping without a bed net who resided in households with: i) no bed net; ii) all bed nets used (intra-household access); and iii) at least one unused bed net. Ownership, intra-household access, and non-use of available bed nets were all associated with the child's age and the mother's relationship to the head of the household. Intra-household access was strongly associated with provincial residence, where the child was born and frequency of reading newspapers. Furthermore, disuse of available nets for children was associated with marital status, bed net use of the head of the household, and residing in rural communities at higher elevations. Improving bed net/long-lasting insecticide treated nets (LLIN) use in Kenya requires a multi-faceted approach that addresses the complexity of the behavioral, social and economic drivers of non-use.

\section{Introduction}

Use of mosquito nets, and particularly insecticide treated nets (ITN) and long-lasting insecticide treated nets (LLIN), is considered to be one of the strongest strategies in the fight against malaria. It has been shown to reduce all-cause mortality and morbidity in young children. ${ }^{1,2}$ Yet not all available bed nets are used regularly. Identifying factors impeding and promoting bed net use is critical as small residual pockets of transmission can lead to resurgence if control programs collapse or donor interest fades. ${ }^{3,4}$ Recent studies have demonstrated that a decline in bed net ownership and use can occur quickly even after large free-distribution programs. ${ }^{5}$

Kenya has the fifth highest burden of malaria in the world. ${ }^{6}$ There were 9.7 million reported cases of clinical malaria in 2007, accounting for $30 \%$ of outpatient consultations. ${ }^{7}$ Kenya has taken considerable steps to reduce the burden of malaria in the past decade by participating in and expanding control programs that include the use of LLIN and ITN, but significant gaps remain in achieving the Abuja targets. ${ }^{7}$ In 1999, under the first Kenyan National Malaria Strategy (KNMS), Kenya's Division of Malaria Control (DOMC) of the Ministry of Public Health and Sanitation (MOPHS) first recommended that nets should be provided to vulnerable populations (children under five years of age and pregnant women) at no charge. ${ }^{8,9}$ Prior to implementation of the KNMS, access to nets was limited. Since that time, both government and non-governmental organizations have led major ITN distribution programs. The most recent report from the Kenya Demographic and Health Survey ${ }^{10}$ found that $61 \%$ of households nationwide own at least one mosquito net (treated or untreated) and $56 \%$ report own at least one ITN. Nationwide, $51 \%$ of children under five years of age and $53 \%$ of pregnant women had slept under a mosquito net the night prior to the interview..$^{10}$ However, in 2010, with the new National Malaria Strategy (2009-2017), the recommendation changed from coverage of the at-risk populations to universal coverage at the level of one net for every 2 people. ${ }^{7}$

In this study, we explored the continuum of bed net use in children under five years of age from ownership to intra-household distribution and disuse of available bed nets in the home. Ownership, the first step in prevention, has been strongly associated with household wealth. ${ }^{11-16}$ It is not surprising then that free distribution of ITN were more effective in reducing disparities in Kenya while social marketing and subsidized low cost ITN were less effective. ${ }^{14}$ Other factors traditionally associated with ITN ownership include education level of the head of the household, ${ }^{12,15,16}$ knowledge of how malaria is transmitted, ${ }^{5}$ region of residence ${ }^{17}$ and presence of an individual from a high-risk group in the household. ${ }^{12}$

It has been demonstrated that when a community has high ITN coverage, even those who are not sleeping under the bed nets have a reduced risk of malaria infection, ${ }^{18,19}$ however the highest protective efficacy is still provided to those directly covered by ITN. ${ }^{20}$ Because of their high level of effectiveness, many malaria control programs focus on increasing ownership through the distribution of free or subsidized ITN. Owning the bed net is the first step, ensuring actual use of the ITN is the next.
Correspondence: Kacey C. Ernst, Division of Epidemiology and Biostatistics, School of Public Health, University of Arizona, 1295 N Martin Ave. Tucson, AZ 85724 USA.

Tel. +1.520.626.7374 - Fax: +1.520.626.2767.

E-mail: kernst@email.arizona.edu

Key words: bed nets, access, malaria, Kenya, ownership, disuse.

Acknowledgments: the authors would like to thank the research teams in Kenya and USAID who made the collection of the Demographic and Health Survey data possible. Partial support for this work is from the Health Resources and Services Administration, Maternal and Child Health Training Grant T76MC04925.

Conflicts of interests: the authors declare no potential conflicts of interests.

Contributions: KE data analysis and manuscript writing; MA manuscript writing, reference research; SM manuscript reviewing and analysis review.

Received for publication: 26 July 2011 .

Revision received: 25 November 2011.

Accepted for publication: 12 January 2011.

This work is licensed under a Creative Commons Attribution NonCommercial 3.0 License (CC BYNC 3.0).

(C) Copyright K.C. Ernst et al., 2012

Licensee PAGEPress, Italy

Malaria Reports 2012; 2:e1

doi:10.4081/malaria.2012.e1

Much is still unclear ${ }^{21}$ and differences in culture and context are likely to have an impact on use, but nonuse, and, and even misuse, of ITN is widely reported. ${ }^{16,22-25}$ The fact that ITN can reduce the risk of malaria may not be well recognized in some areas and individuals have consistently reported using ITN because they regard mosquitoes to be a nuisance, not to prevent transmission of malaria. ${ }^{22,23,26}$ This may be due to lack of knowledge about malaria transmission and/or a lower perceived risk of the disease ${ }^{5,23,26,27}$ Discomfort, particularly in higher temperature climates and inconvenience are other frequently cited reasons for not using mosquito nets. ${ }^{21}$

We undertook an analysis of the 2008 Kenya Demographic and Health Survey data (KDHS) to determine factors associated with three categories of children under five years of age not sleeping under a bed net: i) Ownership: the child does not sleep under a bed net because there are none in the household; ii) Intrahousehold bed net access: all bed nets are being used and there is none for the child to sleep under; iii) Non-use: there are bed nets available in the home that are not being used. 
While KDHS does not explicitly explore these questions, we used indicators that may be indirectly related to perceived risk, power dynamics in the household, logistical difficulties in hanging nets, and exposure to media that may play a role in bed net access and compliance.

\section{Materials and Methods}

\section{Data source}

We used secondary data from the 2008 KDHS. This is a nationally representative survey that draws from a master sampling frame maintained by the Kenyan National Bureau of Statistics. A two-stage sampling scheme was employed. In the first stage, data collection points or clusters were chosen from the sampling frame, while the second stage further drew systematic sampling of households from within the cluster. The sample is designed to accurately represent all eight Kenyan provinces. Urban areas are over-sampled to allow comparisons with rural areas (Figure 1).

All women in the selected households aged 15-49 years in the house the night before the survey were eligible for interview, regardless of whether they were usual residents or visitors. For the purposes of this analysis, the children's recode data was used. This dataset includes all children born within the last five years to eligible mothers. The children's recode was integrated into maternal and household data found in those corresponding datasets to obtain information on environmental, social and economic determinants of bed net use. Of the 6079 children included in the database, 373 had died, 205 were not currently living with the respondent, and 13 did not report bed net use, leaving 5488 for analysis.

\section{Exposure and outcome definitions}

Bed net use outcomes were classified into four categories:

i) children sleeping under a bed net of any kind; ii) children that did not sleep under a net the night previously because the household owned none; iii) children who did not sleep under a net the night previously and all bed nets in the home were being used by other residents; iv) children that did not sleep under a net the night previously even when there were unused bed nets in the household.

As we were interested in issues related to compliance in addition to access, we chose to define sleeping under any bed net as our comparison outcome.

\section{Defining exposures}

\section{Child- level variables}

We assessed child's age in a narrow age range, comparing children aged under 12 months, 12-23 months, 24-35 months, 36-47 months and 48-59 months. Sex differences were assessed but not presented, as no differences were seen in any category.

\section{Maternal-level variables}

Demographics of the mother were assessed for relationships in all categories, including education level, marital status and age. The relationship to household head was categorized as self, spouse, daughter, daughter-inlaw or other. The other category consisted of numerous classifications with small sample sizes (grandchild, parent, parent-in-law, sister, other relative, adopted/foster child, not related, niece by blood, niece by marriage). We also explored associations between multiple media exposures, as a proxy for malaria control information campaigns. Access to freely provided bed nets was approximated by place most recent child was born. Perceived risk of illness was captured using the response to whether a child's fever was a trigger to seek medical care.

\section{Household-level variables}

Household wealth quintiles were available in the original recode files. The wealth index is calculated using a household's ownership of selected durable goods, housing construction materials, and the type of water and sanitation facilities available to the household. Principal component analysis is used to create a standardized score that is then divided into quintiles. In households where bed nets were available, we also assessed the influence of the head of the household sleeping under a bed net and the available bed net to person ratio in the household. We dichotomized the ratio to be below or above the target level of one bed net for every 2 people in a household.

\section{Community-level variables}

As some sampling clusters were quite small $(n<20)$, generated community at the district level. Geocoded cluster points were joined with available district level shapefiles using ArcGIS. We calculated the proportion of women who reported fever as a trigger to seek care, households living in the lowest quintile of wealth, and households owning at least one bed net in each district. We divided the resulting proportions into quartiles and generated dummy variables for use in the analysis. Elevation of the cluster was not aggregated and was was broken into $200 \mathrm{~m}$ increments. Province of residence was also examined.

Variables included in each sub-analysis differed according to the theoretical framework of analysis.

\section{Statistical analyses}

Initial exploration of variables included investigating frequencies, means and distribu-

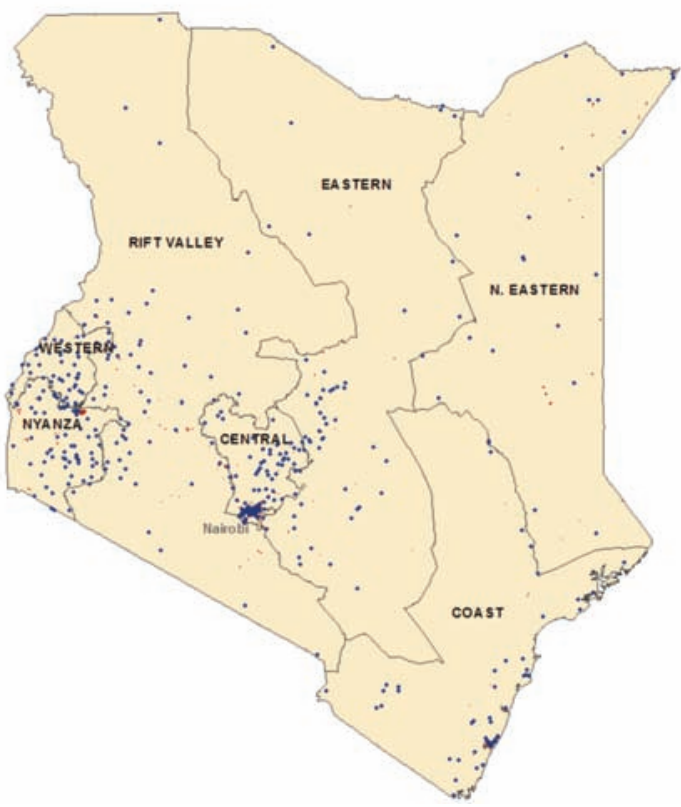

Figure 1. Map of demographic and health survey cluster locations (offset $1 \mathrm{~km}$ to $10 \mathrm{~km}$ ) and Kenyan provincial boundaries. DHS sampling is proportional to size and representative at the provincial level. Urban areas are shown in red. 
tions of outcome and exposure variables. Dummy variables were created to group continuous variables (e.g. wealth, age) into nonlinear categories. Relationships between outcome measures and explanatory variables were initially explored by calculating odds ratios using bi-variate logistical regression models. We adjusted all models for sampling weights.

Due to the nested nature of the data, multilevel modeling was used to create the final models. Traditional logistical regression models tend to overestimate the effects of exposure on the outcome. Proc GLIMMIX was used in SAS V 9.2. with a binary distribution and a logit link function. Three separate multilevel logistical regression models were then created. Random effects were included for the household and sampling cluster levels. Variables were inserted sequentially into the final model in rank order of bivariate F-values. As each new variable was entered, the effect on current variables in the model were assessed. If inclusion of the new variable resulted in a change greater than $20 \%$ of the previous included variables, the two were tested for effect modification, confounding and multi-collinearity. In the event that the variables were highly co-linear, the variable with the greatest association to the outcome was chosen to remain in the model. No interaction terms were significant. If at least one of a set of dummy variables was significant, all of that set were left in the model (e.g. if being in the wealthiest category was associated with not having a bed net in the household, all of the other wealth categories were kept in the model). gender (data not shown). Even in the narrow age group of $0-5$ years, there was a notable decline in bed net use in older ages. Of children under 12 months old, $63.7 \%$ slept under a bed net while only $48.6 \%$ of children aged 48 60 months of age slept under a bed net (Figure 3 ). Even after adjustment the trend was significant. Children 48-59 months of age were approximately. twice as likely to sleep without a bed net across all non-use categories (Tables 1-3).

\section{Maternal factors}

Multiple maternal factors were associated with bed net use. Children from households without bed nets were less likely to have highly educated mothers but use of owned bed nets did not differ by maternal education level. Children born to mothers who gave birth in private or government clinics were half as likely to not own a bed net or to sleep under bed nets that were available in the household. Maternal relationship to the head of the household was highly correlated with all outcomes. As compared to children whose mothers were the spouses of the head of the household, nearly all others were more likely to sleep without a bed net across all three non-use categories. The greatest disparity was seen with children whose mothers were others (i.e. grandchild, parent, parent-in-law, sister, other relative, adopted/foster child, not related, niece by blood, niece by marriage). Children of women who were not married were also generally less likely to be sleeping under a bed net for any reason in bivariate analyses. The impact of media exposure on bed net use was minimal.

\section{Household factors}

In bi-variate analyses, those children residing in households in the wealthier classes were less likely to sleep without a bed net for all three non-use categories. If a head of household did not sleep under a bed net it was associated with a near 30 -fold increase in the odds that the child was not sleeping under a bed net despite having available nets in the household. There was no association between use by head of household and children not using a bed net when all were already being used. Children not sleeping under bed nets when all bed nets were used was associated with households where the bed net ratio was less than 2 per person.

\section{Community factors}

Regional and urban rural disparities were noted across all non-use categories. Children in urban areas were approximately half as likely to sleep without a bed net for all three reasons. With increases in elevation, there were increasing odds of not using a bed net across categories.

\section{Multivariate associations}

Final models of factors associated with the different non-use categories are described below. Ownership: children who slept without a bed net because there were none in the

\section{Results}

\section{Results}

\section{Ownership}

A total of 5,488 children were included in the analysis (Figure 2). Over half of the children slept under a bed net of some kind $(n=3082$, $56 \%$ ). The majority of these were sleeping under a net that had been treated with insecticide $(\mathrm{n}=2866,93 \%)$. Of those not sleeping under a bed net (2406, 44\% of total children), 1308 (54\% of those without a bed net) did not have a bed net in the household, 425 (18\%) slept in household with at least one bed net but they were all being used by other individuals and 673 (28\%) were sleeping without a bed net when there was at least one unused in the household.

\section{Descriptive results}

\section{Child factors}

Child's gender and age were examined in relationship to bed net use. No disparities were found in any bed net use category and

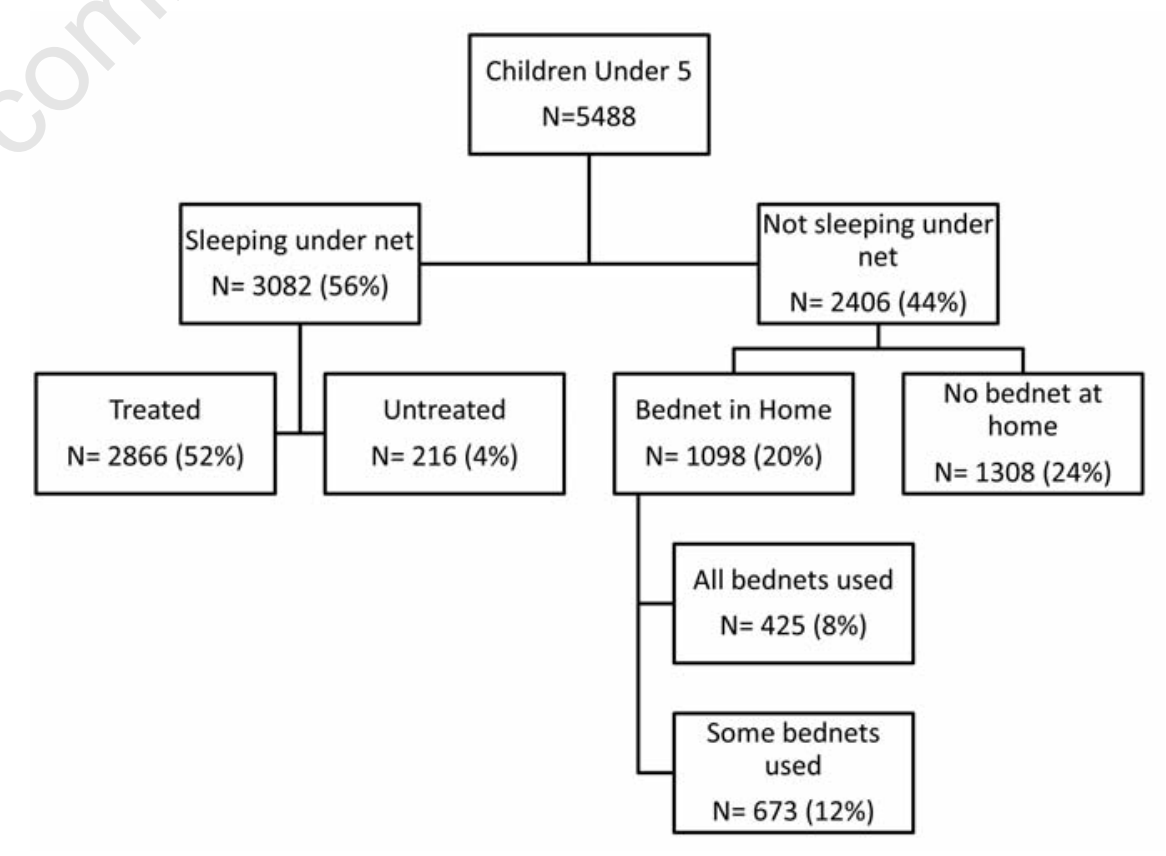

Figure 2. Distribution of bed net outcomes in children under five years of age. All percentages represent the overall percentage of the total children under study. 
household were older: 49-59 months old compared to < 12 months; OR=2.0 (1.5, 2.7) $\mathrm{P}<0.0001$. Their mothers were more likely to be extended family members (mother is spouse of head of household compared to mother who is daughter, etc: $\mathrm{OR}=3.1(2.1,4.8)$ $\mathrm{P}<0.001$. They were less likely to have delivered in a public $(\mathrm{OR}=0.7(0.5,0.9) \mathrm{P}=0.003)$ or private $(\mathrm{OR}=0.6(0.4,1.0) \mathrm{P}=0.03)$ clinic, less likely to recognize fever as a trigger to seek medical care $(0 R=0.8(0.6,1.0) \mathrm{P}=0.05)$, less likely to listen to the radio on a daily basis $(0 R=0.4(0.3,0.6) \mathrm{P}<0.0001)$, and less likely to watch TV $(0 R=0.5(0.3,0.8) \quad \mathrm{P}=0.0008)$. Households were less likely to be in the highest wealth quintile $(\mathrm{OR}=0.4 \quad(0.2,0.7)$ $\mathrm{P}=0.0006)$. Children residing at higher elevations $(\mathrm{OR}=1.2(1.1,1.2) \mathrm{P}<0.0001)$ and/or in central province were three times more likely to reside in households without bed nets $(\mathrm{OR}=3.6(1.3,9.8) \mathrm{P}=0.01)$. Children in homes without bed nets were less likely to reside in a community with high bed net ownership $(\mathrm{OR}=0.1(0.0,0.2) \mathrm{P}<0.0001)$.
Intra-household access: those children sleeping without a net because all nets were being used were older $(\mathrm{OR}=3.0(2.1,4.3)$ $\mathrm{P}<0.0001$ ): children 48-59 months compared to $<12$ months) and had mothers who were extended family members $(\mathrm{OR}=3.4(2.0,6.0)$ $\mathrm{P}<0.0001)$. They were less likely to have mothers who read newspapers and magazines frequently $(\mathrm{OR}=0.6(0.4,0.9) \mathrm{P}=0.007)$ and to reside in Nairobi $(\mathrm{OR}=0.3(0.1,0.7) \mathrm{P}=0.008)$, central $(0 \mathrm{O}=0.4(0.2,0.9) \mathrm{P}=0.02)$, coast ( $0 \mathrm{R}=0.5(0.2,1.0) \mathrm{P}=0.04)$ or northeastern provinces $(\mathrm{OR}=0.4(0.2,0.8) \mathrm{P}=0.007)$.

Non-use of nets: those children sleeping without a net when one was available were more likely to be older $(\mathrm{OR}=2.3(1.5,3.4)$ $\mathrm{P}<0.0001)$, have mothers who are extended family members $(5.6(2.5,12.6) \mathrm{P}<0.0001)$, sleep in a household where the head of household also does not sleep with a bed net $(\mathrm{OR}=29.5(22.0,39.5) \mathrm{P}<0.0001)$ and reside in a community at higher elevation $(\mathrm{OR}=1.1$ (1.0, 1.1) $P=0.01$ ) and were less likely to reside in urban areas $(\mathrm{OR}=0.5(0.3,0.8) \mathrm{P}=0.001)$.

\section{Discussion}

Bed net use is generally defined as prevalence of children and other groups sleeping under a net i) regardless of net ownership or ii) in homes that own at least one bed net. Exploration of access and compliance within the same study is not common. Our analysis explicitly separated access from compliance and looked at the relative factors predicting each of them. We found that there are complex factors driving these different outcomes. Factors impacting compliance seemed to be primarily related to risk of malaria and use of bed nets by the head of household. Intrahousehold access appeared to be related to both malaria risk and economics of the household, including allocation of resources. Ownership was more strongly associated with the household wealth and the education level of the mother. Below we discuss some of the key findings.
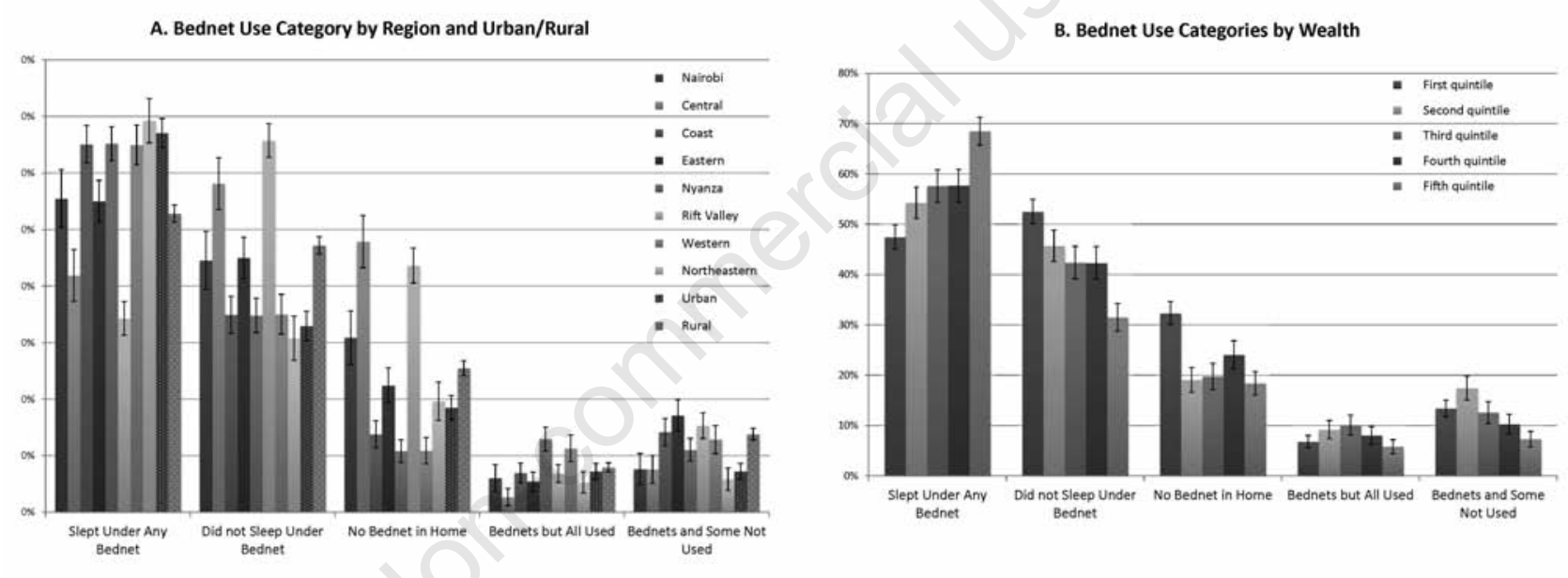

C. Bednet Use Categories by Education

D. Bednet Use Categories by Age Group
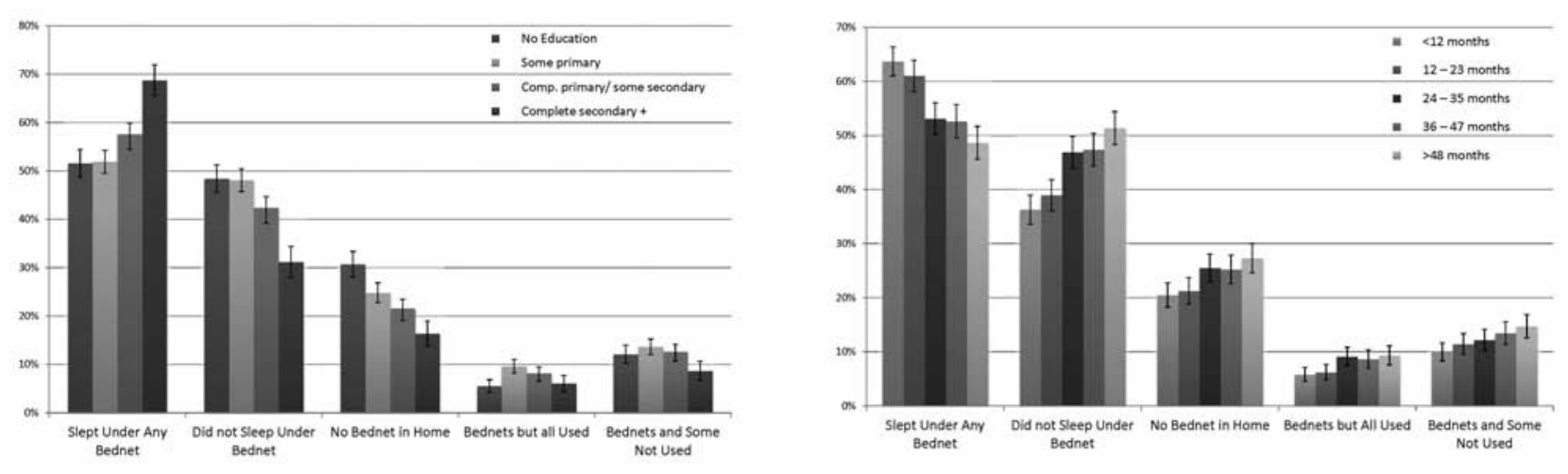

Figure 3. Distribution of bed net ownership and use outcomes for children under five years of age by (A) geographical area: province and urban/rural, (B) household quintile of wealth as determined by ownership of durable goods, (C) highest level of education attained by child's mother, (D) age of the child in months. Error bars indicate $95 \%$ CI. 


\section{Child age}

Overall use is fairly high in children under five years of age, but still nearly one-third of children do not sleep under a net (Figure 2). There was a strong relationship between age and net use even in this narrow age range. The trend is consistent, with 4 year olds being 2 times more likely to sleep without a bed net across all outcome categories. When looking at intra-household access to the net, there is an even greater children age 4 being 3 times more likely to sleep without a bed net. The degree to which a cohort effect has on this result is not clear. Free distribution of bed nets to pregnant women and children under five years of age was initiated in 2006; the DHS data were collected during 2008. Therefore, it would be

Table 1. Crude and adjusted associations of children sleeping with a bed net compared to those sleeping without a bed net even when one was available and unused in the household. Ref, the reference dummy variable for categorical analysis; N/S, not signficant to the $\mathbf{P}=\mathbf{0 . 0 5}$ level after adjustment for other factors.

\begin{tabular}{|c|c|c|c|}
\hline Explanatory variables & $\begin{array}{l}\text { Sample size } \\
(\mathrm{n}=3755)\end{array}$ & Crude odds ratio & Adjusted odds ratio \\
\hline \multicolumn{4}{|c|}{ Individual child factors } \\
\hline $\begin{array}{l}\text { Age } \\
\text { <1 year } \\
\text { 12-23 months } \\
\text { 24-35 months } \\
\text { 36-47 months } \\
\text { >48 months }\end{array}$ & $\begin{array}{l}914(24.3) \\
791(21.1) \\
721(19.2) \\
678(18.1) \\
651(17.3)\end{array}$ & $\begin{array}{c}\text { Ref } \\
1.2(0.9,1.7) \mathrm{P}=0.23 \\
1.6(1.1,2.2) \mathrm{P}=0.005 \\
1.7(1.3,2.4) \mathrm{P}=0.0007 \\
2.0(1.5,2.8) \mathrm{P}<0.0001\end{array}$ & $\begin{array}{c}\text { Ref } \\
1.3(0.9,2.0) \mathrm{P}=0.14 \\
1.5(1.0,2.2) \mathrm{P}=0.05 \\
1.8(1.2,2.7) \mathrm{P}=0.003 \\
2.3(1.5,3.4) \mathrm{P}<0.0001\end{array}$ \\
\hline \multicolumn{4}{|c|}{ Maternal factors } \\
\hline $\begin{array}{l}\text { Age } \\
\text { 15-24 years } \\
\text { 25-39 years } \\
\text { 40-49 years }\end{array}$ & $\begin{array}{c}1231(32.8) \\
2305(61.4) \\
219(5.8)\end{array}$ & $\begin{array}{c}\text { Ref } \\
1.2(0.9,1.6) \mathrm{P}=0.10 \\
1.1(0.7,1.8) \mathrm{P}=0.66\end{array}$ & $\mathrm{~N} / \mathrm{S}$ \\
\hline $\begin{array}{l}\text { Education } \\
\text { No education } \\
\text { Some primary } \\
\text { Comp. primary/ some secondary } \\
\text { Complete secondary/ higher }\end{array}$ & $\begin{array}{c}757(20.2) \\
2067(55.1) \\
931(24.8) \\
242(6.4)\end{array}$ & $\begin{array}{c}\text { Ref } \\
0.9(0.7,1.3) \mathrm{P}=0.64 \\
0.8(0.5,1.2) \mathrm{P}=0.32 \\
0.8(0.5,1.4) \mathrm{P}=0.43\end{array}$ & $\mathrm{~N} / \mathrm{S}$ \\
\hline $\begin{array}{l}\text { Relation to household head } \\
\text { Spouse } \\
\text { Self } \\
\text { Daughter } \\
\text { Daughter-in-law } \\
\text { Other }\end{array}$ & $\begin{array}{c}2438(64.9) \\
859(22.8) \\
189(5.0) \\
145(3.9) \\
115(3.1)\end{array}$ & $\begin{array}{c}\text { Ref } \\
1.4(1.1,1.8) \mathrm{P}=0.01 \\
2.3(1.5,3.6) \mathrm{P}=0.0003 \\
1.6(0.9,2.8) \mathrm{P}=0.08 \\
3.2(1.8,5.5) \mathrm{P}<0.0001\end{array}$ & $\begin{array}{c}\text { Ref } \\
2.3(1.6,3.3) \mathrm{P}<0.0001 \\
3.2(1.6,6.4) \mathrm{P}=0.001 \\
1.2(0.6,2.2) \mathrm{P}=0.63 \\
5.6(2.5,12.6) \mathrm{P}<0.0001\end{array}$ \\
\hline $\begin{array}{l}\text { Marital status } \\
\text { Married - only wife } \\
\text { Married - first wife } \\
\text { Married - lower wife } \\
\text { Never married } \\
\text { Living together (LT) } \\
\text { Widowed/ divorced/ NLT } \\
\end{array}$ & $\begin{array}{l}2630(70.0) \\
167(4.5) \\
319(8.5) \\
177(4.7) \\
202(5.4) \\
260(6.9)\end{array}$ & $\begin{array}{c}\text { Ref } \\
1.1(0.6,1.9) \mathrm{P}=0.79 \\
1.3(0.9,1.9) \mathrm{P}=0.19 \\
1.3(0.8,2.1) \mathrm{P}=0.33 \\
1.3(0.8,2.1) \mathrm{P}=0.35 \\
2.0(1.3,3.0) \mathrm{P}=0.0007\end{array}$ & $\begin{array}{c}\text { Ref } \\
0.8(0.4,1.6) \mathrm{P}=0.58 \\
1.1(0.7,1.8) \mathrm{P}=0.65 \\
0.3(0.2,0.7) \mathrm{P}=0.007 \\
1.0(0.6,1.9) \mathrm{P}=0.93 \\
0.8(0.5,1.5) \mathrm{P}=0.56\end{array}$ \\
\hline $\begin{array}{l}\text { Birthing location } \\
\text { Home } \\
\text { Public clinic } \\
\text { Private clinic }\end{array}$ & $\begin{array}{l}2047(54.5) \\
1275(33.9) \\
427(11.4)\end{array}$ & $\begin{array}{c}\text { Ref } \\
0.7(0.5,0.9) \mathrm{P}=0.002 \\
0.6(0.4,0.9) \mathrm{P}=0.009\end{array}$ & $\mathrm{~N} / \mathrm{S}$ \\
\hline Child's fever is trigger to seek care & $3087(82.5)$ & $1.0(0.8,1.4) \mathrm{P}=0.85$ & $\mathrm{~N} / \mathrm{S}$ \\
\hline $\begin{array}{l}\text { Reads Newspaper/magazine } \\
\text { Not at all } \\
\text { Less than once a week } \\
\text { At least once a week } \\
\text { Almost every day }\end{array}$ & $\begin{array}{c}2479(66.0) \\
633(16.9) \\
493(13.1) \\
141(3.8)\end{array}$ & $\begin{array}{c}\text { Ref } \\
0.9(0.7,1.3) \mathrm{P}=0.94 \\
0.9(0.6,1.3) \mathrm{P}=0.61 \\
0.5(0.2,1.0) \mathrm{P}=0.05\end{array}$ & $\mathrm{~N} / \mathrm{S}$ \\
\hline $\begin{array}{l}\text { Listens to Radio } \\
\text { Not at all } \\
\text { Less than once a week } \\
\text { At least once a week } \\
\text { Almost every day } \\
\end{array}$ & $\begin{array}{c}793(21.1) \\
336(8.9) \\
575(15.3) \\
2047(54.5)\end{array}$ & $\begin{array}{c}\text { Ref } \\
1.3(0.9,2.1) \mathrm{P}=0.21 \\
1.5(1.0,2.1) \mathrm{P}=0.04 \\
0.8(0.6,1.2) \mathrm{P}=0.41\end{array}$ & $\mathrm{~N} / \mathrm{S}$ \\
\hline $\begin{array}{l}\text { Watches TV } \\
\text { Not at all } \\
\text { Less than once a week } \\
\text { At least once a week } \\
\text { Almost every day }\end{array}$ & $\begin{array}{l}2404(64.0) \\
370(9.9) \\
282(7.5) \\
699(18.6) \\
\end{array}$ & $\begin{array}{c}\text { Ref } \\
0.8(0.5,1.2) \mathrm{P}=0.22 \\
0.7(0.4,1.1) \mathrm{P}=0.11 \\
0.6(0.5,0.9) \mathrm{P}=0.008\end{array}$ & $\mathrm{~N} / \mathrm{S}$ \\
\hline
\end{tabular}

To be continued on next page 
Table 1. Continued from previous page.

\begin{tabular}{|c|c|c|c|}
\hline Explanatory variables & $\begin{array}{c}\text { Sample size } \\
(\mathrm{n}=3755)\end{array}$ & Crude odds ratio & Adjusted odds ratio \\
\hline \multicolumn{4}{|c|}{ Household factors } \\
\hline $\begin{array}{l}\text { Wealth (child resides in household of) } \\
\text { First quintile } \\
\text { Second quintile } \\
\text { Third quintile } \\
\text { Fourth quintile } \\
\text { Fifth quintile }\end{array}$ & $\begin{array}{l}995(26.5) \\
703(18.7) \\
625(16.6) \\
610(16.3) \\
822(21.9)\end{array}$ & $\begin{array}{c}\text { Ref } \\
1.1(0.8,1.6) \mathrm{P}=0.49 \\
0.8(0.5,1.1) \mathrm{P}=0.13 \\
0.6(0.4,0.9) \mathrm{P}=0.02 \\
0.4(0.3,0.6) \mathrm{P}<0.0001\end{array}$ & $\mathrm{~N} / \mathrm{S}$ \\
\hline $\begin{array}{l}\text { Religious practices } \\
\text { No religion } \\
\text { Catholic } \\
\text { Protestant } \\
\text { Muslim } \\
\end{array}$ & $\begin{array}{c}110(2.9) \\
666(17.7) \\
2114(56.3) \\
834(22.2)\end{array}$ & $\begin{array}{c}\text { Ref } \\
0.8(0.4,1.5) \mathrm{P}=0.56 \\
0.6(0.4,1.2) \mathrm{P}=0.14 \\
0.5(0.3,0.9) \mathrm{P}=0.03\end{array}$ & $\mathrm{~N} / \mathrm{S}$ \\
\hline Indoor residual spray & $207(5.5)$ & $1.3(0.8,2.1) \mathrm{P}=0.32$ & $\mathrm{~N} / \mathrm{S}$ \\
\hline Household head does not sleep under a bed net & $2628(70.0)$ & $27.5(20.1,36.3) \mathrm{P}<0.0001$ & $29.5(22.0,39.5) \mathrm{P}<0.0001$ \\
\hline Less than 1 bed net for 2 people & $3098(82.5)$ & $2.3(1.7,3.3) \mathrm{P}<0.0001$ & $\mathrm{~N} / \mathrm{S}$ \\
\hline \multicolumn{4}{|c|}{ Cluster/ community factors } \\
\hline $\begin{array}{l}\text { Region } \\
\text { Nairobi } \\
\text { Central } \\
\text { Coast } \\
\text { Eastern } \\
\text { Nyanza } \\
\text { Rift Valley } \\
\text { Western } \\
\text { Northeastern } \\
\text { Urban }\end{array}$ & $\begin{array}{c}231(6.1) \\
222(5.9) \\
638(17.0) \\
505(13.5) \\
724(19.3) \\
486(12.9) \\
551(14.7) \\
398(10.6) \\
956(25.5)\end{array}$ & $\begin{array}{c}\text { Ref } \\
1.4(0.7,3.1) \mathrm{P}=0.34 \\
1.4(0.7,2.7) \mathrm{P}=0.28 \\
2.1(1.1,3.9) \mathrm{P}=0.02 \\
1.2(0.6,2.2) \mathrm{P}=0.61 \\
3.2(1.7,6.1) \mathrm{P}=0.0004 \\
1.5(0.8,2.8) \mathrm{P}=0.24 \\
0.6(0.3,1.3) \mathrm{P}=0.17 \\
0.4(0.3,0.6) \mathrm{P}<0.0001\end{array}$ & $0.5(0.3,0.8) \mathrm{P}=0.001$ \\
\hline $\begin{array}{l}\text { Proportion seeking care for fever } \\
1^{\text {st }} \text { quartile }(<36 \%) \\
2^{\text {nd }} \text { quartile }(37-44 \%) \\
3^{\text {rd }} \text { quartile }(45-52 \%) \\
4^{\text {th }} \text { quartile }(>52 \%)\end{array}$ & $\begin{array}{c}1005(26.8) \\
969(25.8) \\
1018(27.1) \\
763(20.3)\end{array}$ & $\begin{array}{c}\text { Ref } \\
1.0(0.7,1.4) \mathrm{P}=0.92 \\
0.6(0.4,0.9) \mathrm{P}=0.01 \\
0.7(0.4,1.0) \mathrm{P}=0.08\end{array}$ & $0.0(0.0,0.0) \times-0.00$ \\
\hline $\begin{array}{l}\text { Elevation } \\
\quad 200 \text { meter increase }\end{array}$ & N/A & $1.1(1.0,1.1) \mathrm{P}=0.01$ & $1.1(1.0,1.1) \mathrm{P}=0.01$ \\
\hline $\begin{array}{l}\text { Time of Interview } \\
\text { November } \\
\text { December } \\
\text { January } \\
\text { February } \\
\end{array}$ & $\begin{array}{c}860(22.9) \\
881(23.5) \\
1082(28.9) \\
913(24.3) \\
\end{array}$ & $\begin{array}{c}\text { Ref } \\
0.9(0.6,1.4) \mathrm{P}=0.54 \\
1.3(0.9,1.9) \mathrm{P}=0.23 \\
1.5(1.0,2.3) \mathrm{P}=0.05\end{array}$ & $\mathrm{~N} / \mathrm{S}$ \\
\hline
\end{tabular}

expected that children under two years of age would be more likely to live in households that own bed nets, but this age gap persists even with issues of compliance. Perhaps emphasis on the use of bed nets during distribution has also improved compliance. Regardless of the underlying reasons, these results indicate that the youngest and likely most vulnerable children are indeed protected more regularly from infectious bites.

These results may have significant implications for meeting the targeted objective of every household member sleeping under a net. If compliance with bed net use is reduced across even this narrow age range, this could imply that it will be that much harder to get older children and adults to comply with using bed nets. While this analysis did not focus on older children and adults, a cursory assessment of the entire household reveals that approximately one-fifth of households had bed nets that were not being used, and in $71 \%$ of those households at least one person was sleeping without a bed net. Indeed, in $72 \%$ of all households surveyed, there was at least one person who had slept without a bed net the night previous, indicating a significant gap between field reality and the targeted objective of universal ITN coverage set by the Ministry of Public Health and Sanitation. ${ }^{7}$

\section{Alternative control measures}

It was thought that perhaps households that did not use an ITN were in fact using alternative malaria control measures, such as indoor residual spray (IRS). IRS is highly effective and more commonly used in highland areas of Kenya where incidence is low. ${ }^{28}$ Upon analysis, IRS was found to be reported in a very small percentage of households (5.6\%) and while households without bed nets were also less likely to have spray in bi-variate analysis, this association disappeared after adjustment for other factors. This indicates that, if anything, sleeping under a bed net is correlated with having additional control measures in place instead of alternative ones.

\section{Family inter-relationship dynamics}

Our results indicate that extended family members residing in households may be marginalized when it comes to all aspects of bed net use. As seen in previous studies in Kenya, children sleeping without a bed net across all categories are more likely to have mothers who are not the head of the household or the spouse of the head of the household. ${ }^{29}$ The magnitude of the association is strongest for intra-household distribution with children sleeping without a bed net when all the bed 
Table 2. Crude and adjusted associations between explanatory factors and children sleeping under a bed net compared to those sleeping without a bed net in homes where all bed nets were being used. Ref, the reference dummy variable for categorical analysis; N/S, not signficant to the $\mathbf{P}=\mathbf{0 . 0 5}$ level after adjustment for other factors.

\begin{tabular}{|c|c|c|c|}
\hline Explanatory variables & $\begin{array}{c}\text { Sample size } \\
(\mathrm{n}=3705)\end{array}$ & Crude odds ratio & Adjusted odds ratio \\
\hline \multicolumn{4}{|c|}{ Individual child factors } \\
\hline $\begin{array}{l}\text { Age } \\
<1 \text { year } \\
12-23 \text { months } \\
24-35 \text { months } \\
36-47 \text { months } \\
>48 \text { months }\end{array}$ & $\begin{array}{l}862(24.6) \\
733(20.9) \\
687(19.6) \\
629(17.9) \\
596(17.0)\end{array}$ & $\begin{array}{c}\text { Ref } \\
1.1(0.8,1.6) \mathrm{P}=0.57 \\
2.0(1.4,2.7) \mathrm{P}<0.0001 \\
1.9(1.4,2.7) \mathrm{P}=0.0002 \\
2.2(1.6,3.1) \mathrm{P}<0.0001\end{array}$ & $\begin{array}{c}\text { Ref } \\
1.3(0.9,1.9) \mathrm{P}=0.21 \\
2.3(1.6,3.3) \mathrm{P}<0.0001 \\
2.5(1.7,3.6) \mathrm{P}<0.0001 \\
3.0(2.1,4.3) \mathrm{P}<0.0001\end{array}$ \\
\hline \multicolumn{4}{|c|}{ Matemal factors } \\
\hline $\begin{array}{l}\text { Age } \\
\text { 15-24 years } \\
25-39 \text { years } \\
\text { 40-49 years }\end{array}$ & $\begin{array}{c}1208(34.5) \\
2094(59.7) \\
205(5.9)\end{array}$ & $\begin{array}{c}\text { Ref } \\
0.8(0.6,0.9) \mathrm{P}=0.02 \\
1.0(0.6,1.6) \mathrm{P}=0.90\end{array}$ & $\mathrm{~N} / \mathrm{S}$ \\
\hline $\begin{array}{l}\text { Education } \\
\text { No Education } \\
\text { Some primary } \\
\text { Comp. primary/ some secondary } \\
\text { Complete secondary/ higher }\end{array}$ & $\begin{array}{c}679(19.4) \\
1954(55.7) \\
874(24.9) \\
230(6.7)\end{array}$ & $\begin{array}{c}\text { Ref } \\
1.5(1.1,2.0) \mathrm{P}=0.02 \\
0.9(0.6,1.4) \mathrm{P}=0.75 \\
0.8(0.4,1.4) \mathrm{P}=0.37\end{array}$ & $\mathrm{~N} / \mathrm{S}$ \\
\hline $\begin{array}{l}\text { Relation to household head } \\
\text { Spouse } \\
\text { Self } \\
\text { Daughter } \\
\text { Daughter-in-law } \\
\text { Other }\end{array}$ & $\begin{array}{l}2295(65.4) \\
742(21.1) \\
208(5.9) \\
152(4.3) \\
101(2.9)\end{array}$ & $\begin{array}{c}\text { Ref } \\
0.7(0.5,1.0) \mathrm{P}=0.06 \\
4.8(3.4,6.9) \mathrm{P}<0.0001 \\
3.4(2.2,5.3) \mathrm{P}<0.0001 \\
2.8(1.6,4.7) \mathrm{P}=0.0002\end{array}$ & $\begin{array}{c}\text { Ref } \\
0.7(0.5,1.0) \mathrm{P}=0.06 \\
6.3(4.3,9.2) \mathrm{P}<0.0001 \\
4.3(2.7,6.9) \mathrm{P}<0.0001 \\
3.4(2.0,6.0) \mathrm{P}<0.0001\end{array}$ \\
\hline $\begin{array}{l}\text { Marital status } \\
\text { Married - only wife } \\
\text { Married - first wife } \\
\text { Married - lower wife } \\
\text { Never married } \\
\text { Living together (LT) } \\
\text { Widowed/divorced/NLT } \\
\end{array}$ & $\begin{array}{l}2451(70.0) \\
157(4.5) \\
288(8.2) \\
194(5.5) \\
188(5.4) \\
229(6.5)\end{array}$ & $\begin{array}{c}\text { Ref } \\
1.2(0.7,2.0) \mathrm{P}=0.61 \\
1.2(0.8,1.9) \mathrm{P}=0.29 \\
2.9(2.0,4.3) \mathrm{P}<0.0001 \\
1.3(0.8,2.2) \mathrm{P}=0.24 \\
1.6(1.1,2.5) \mathrm{P}=0.02\end{array}$ & $\mathrm{~N} / \mathrm{S}$ \\
\hline $\begin{array}{l}\text { Birthing location } \\
\text { Home } \\
\text { Public clinic } \\
\text { Private clinic }\end{array}$ & $\begin{array}{l}1881(53.6) \\
1217(34.7) \\
402(11.5)\end{array}$ & $\begin{array}{c}\text { Ref } \\
0.7(0.5,0.9) \mathrm{P}=0.002 \\
0.3(0.3,0.7) \mathrm{P}=0.0008\end{array}$ & $\begin{array}{c}\text { Ref } \\
0.7(0.5,0.9) \mathrm{P}=0.01 \\
0.5(0.3,0.9) \mathrm{P}=0.01\end{array}$ \\
\hline Child's fever is trigger to seek care & $2864(81.7)$ & $0.8(0.6,1.1) \mathrm{P}=0.18$ & $\mathrm{~N} / \mathrm{S}$ \\
\hline $\begin{array}{l}\text { Reads newspaper/magazine } \\
\text { Not at all } \\
\text { Less than once a week } \\
\text { At least once a week } \\
\text { Almost every day }\end{array}$ & $\begin{array}{c}2296(65.5) \\
608(17.3) \\
457(13.0) \\
137(3.9)\end{array}$ & $\begin{array}{c}\text { Ref } \\
1.1(0.8,1.5) \mathrm{P}=0.41 \\
0.7(0.5,1.0) \mathrm{P}=0.05 \\
0.5(0.2,1.0) \mathrm{P}=0.05\end{array}$ & $\begin{array}{c}\mathrm{N} / \mathrm{S} \\
0.8(0.5,1.2) \mathrm{P}=0.29 \\
0.6(0.3,0.9) \mathrm{P}=0.02 \\
0.6(0.4,0.9) \mathrm{P}=0.007\end{array}$ \\
\hline $\begin{array}{l}\text { Listens to Radio } \\
\text { Not at all } \\
\text { Less than once a week } \\
\text { At least once a week } \\
\text { Almost every day }\end{array}$ & $\begin{array}{c}727(20.1) \\
310(8.8) \\
524(15.0) \\
1942(55.4)\end{array}$ & $\begin{array}{c}\text { Ref } \\
1.3(0.8,2.0) \mathrm{P}=0.24 \\
1.6(1.1,2.3) \mathrm{P}=0.02 \\
1.0(0.8,1.4) \mathrm{P}=0.9\end{array}$ & $\mathrm{~N} / \mathrm{S}$ \\
\hline $\begin{array}{l}\text { Watches TV } \\
\text { Not at all } \\
\text { Less than once a week } \\
\text { At least once a week } \\
\text { Almost every day }\end{array}$ & $\begin{array}{l}2221(63.3) \\
354(10.1) \\
267(7.6) \\
665(19.0)\end{array}$ & $\begin{array}{c}\text { Ref } \\
0.9(0.6,1.2) \mathrm{P}=0.40 \\
0.6(0.4,1.0) \mathrm{P}=0.06 \\
0.6(0.4,0.8) \mathrm{P}=0.0007\end{array}$ & $\mathrm{~N} / \mathrm{S}$ \\
\hline \multicolumn{4}{|c|}{ Household factors } \\
\hline $\begin{array}{l}\text { Wealth (child resides in household of) } \\
\text { First quintile } \\
\text { Second quintile } \\
\text { Third quintile } \\
\text { Fourth quintile } \\
\text { Fifth quintile }\end{array}$ & $\begin{array}{l}887(25.3) \\
622(17.7) \\
603(17.2) \\
590(16.8) \\
805(23.0)\end{array}$ & $\begin{array}{c}\text { Ref } \\
1.1(0.8,1.5) \mathrm{P}=0.56 \\
1.1(0.8,1.6) \mathrm{P}=0.44 \\
0.9(0.6,1.3) \mathrm{P}=0.63 \\
0.6(0.4,0.8) \mathrm{P}=0.002\end{array}$ & $\mathrm{~N} / \mathrm{S}$ \\
\hline Household head does not sleep under a bed net & $645(18.4)$ & $1.0(0.8,1.4) \mathrm{P}=0.80$ & $\mathrm{~N} / \mathrm{S}$ \\
\hline
\end{tabular}


Table 2. Continued from previous page.

\begin{tabular}{|c|c|c|c|}
\hline Explanatory variables & $\begin{array}{c}\text { Sample size } \\
(\mathrm{n}=3705)\end{array}$ & Crude odds ratio & Adjusted odds ratio \\
\hline \multicolumn{4}{|c|}{ Cluster/ Community Factors } \\
\hline $\begin{array}{l}\text { Region } \\
\text { Nairobi } \\
\text { Central } \\
\text { Coast } \\
\text { Eastern } \\
\text { Nyanza } \\
\text { Rift Valley } \\
\text { Western } \\
\text { Northeastern } \\
\text { Urban }\end{array}$ & $\begin{array}{l}225(6.4) \\
200(5.7) \\
580(16.5) \\
423(12.1) \\
741(21.1) \\
403(11.5) \\
540(15.4) \\
395(11.3) \\
956(27.2)\end{array}$ & $\begin{array}{c}\text { Ref } \\
0.6(0.3,1.3) \mathrm{P}=0.20 \\
1.0(0.6,1.7) \mathrm{P}=0.95 \\
0.9(0.5,1.7) \mathrm{P}=0.83 \\
1.8(1.0,3.1) \mathrm{P}=0.03 \\
1.8(1.0,3.2) \mathrm{P}=0.03 \\
1.6(0.9,2.8) \mathrm{P}=0.10 \\
0.7(0.4,1.4) \mathrm{P}=0.35 \\
0.7(0.5,1.0) \mathrm{P}=0.02\end{array}$ & $\begin{array}{c}0.3(0.1,0.7) \mathrm{P}=0.008 \\
0.4(0.2,0.9) \mathrm{P}=0.02 \\
0.5(0.2,1.0) \mathrm{P}=0.04 \\
0.9(0.5,1.7) \mathrm{P}=0.72 \\
1.0(0.5,1.9) \mathrm{P}=0.96 \\
0.7(0.4,1.4) \mathrm{P}=0.32 \\
0.4(0.2,0.8) \mathrm{P}=0.007 \\
\mathrm{~N} / \mathrm{S}\end{array}$ \\
\hline $\begin{array}{l}\text { Elevation } \\
\quad 200 \text { meter increase }\end{array}$ & & $1.1(1.0,1.1) \mathrm{P}=0.003$ & $\mathrm{~N} / \mathrm{S}$ \\
\hline $\begin{array}{l}\text { Time of interview } \\
\text { November } \\
\text { December } \\
\text { January } \\
\text { February }\end{array}$ & $\begin{array}{c}830(23.7) \\
831(23.7) \\
1014(28.9) \\
818(23.3)\end{array}$ & $\begin{array}{c}\text { Ref } \\
0.7(0.5,0.9) \mathrm{P}=0.03 \\
1.2(0.8,1.6) \mathrm{P}=0.34 \\
0.9(0.7,1.3) \mathrm{P}=0.71\end{array}$ & $\begin{array}{c}\text { Ref } \\
0.5(0.4,0.8) \mathrm{P}=0.0006 \\
0.9(0.7,1.3) \mathrm{P}=0.61 \\
0.8(0.5,1.1) \mathrm{P}=0.12\end{array}$ \\
\hline
\end{tabular}

Table 3. Crude and adjusted odds ratios for associations between explanatory factors of children sleeping without a bed net because the household did not own a bed net as compared to children sleeping under a bed net. Ref, the reference dummy variable for categorical analysis; $\mathrm{N} / \mathrm{S}$, not signficant to the $\mathrm{P}=\mathbf{0 . 0 5}$ level after adjustment for other factors.

\begin{tabular}{|c|c|c|c|}
\hline Explanatory variables & $\begin{array}{c}\text { Sample size } \\
(\mathrm{n}=3705)\end{array}$ & Crude odds ratio & Adjusted odds ratio \\
\hline \multicolumn{4}{|c|}{ Individual child factors } \\
\hline $\begin{array}{l}\text { Age } \\
<1 \text { year } \\
12-23 \text { months } \\
24-35 \text { months } \\
36-47 \text { months } \\
>48 \text { months }\end{array}$ & $\begin{array}{l}1044(23.8) \\
898(20.4) \\
868(19.8) \\
799(18.2) \\
781(17.8)\end{array}$ & $\begin{array}{c}\text { Ref } \\
1.1(0.8,1.4) \mathrm{P}=0.70 \\
1.5(1.2,2.0) \mathrm{P}=0.002 \\
1.5(1.1,1.9) \mathrm{P}=0.009 \\
1.7(1.3,2.2) \mathrm{P}=0.0002\end{array}$ & $\begin{array}{c}\text { Ref } \\
1.1(0.8,1.5) \mathrm{P}=0.54 \\
1.6(1.2,2.2) \mathrm{P}=0.0011 \\
1.5(1.1,2.1) \mathrm{P}=0.006 \\
2.0(1.5,2.7) \mathrm{P}<0.0001\end{array}$ \\
\hline \multicolumn{4}{|c|}{ Maternal Factors } \\
\hline $\begin{array}{l}\text { Age } \\
15-24 \text { years } \\
25-39 \text { years } \\
40-49 \text { years }\end{array}$ & $\begin{array}{c}1472(33.5) \\
2629(59.9) \\
289(6.6)\end{array}$ & $\begin{array}{c}\text { Ref } \\
0.9(0.7,1.1) \mathrm{P}=0.32 \\
1.4(0.9,2.4) \mathrm{P}=0.09\end{array}$ & $\mathrm{~N} / \mathrm{S}$ \\
\hline $\begin{array}{l}\text { Education } \\
\text { No Education } \\
\text { Some primary } \\
\text { Comp. primary/some secondary } \\
\text { Complete secondary/ higher }\end{array}$ & $\begin{array}{c}978(22.3) \\
2399(54.7) \\
1013(23.1) \\
256(5.8)\end{array}$ & $\begin{array}{c}\text { Ref } \\
0.6(0.5,0.9) \mathrm{P}=0.008 \\
0.4(0.3,0.6) \mathrm{P}<0.0001 \\
0.7(0.4,1.2) \mathrm{P}=0.19\end{array}$ & $\mathrm{~N} / \mathrm{S}$ \\
\hline $\begin{array}{l}\text { Relation to household head } \\
\text { Spouse } \\
\text { Self } \\
\text { Daughter } \\
\text { Daughter-in-law } \\
\text { Other }\end{array}$ & $\begin{array}{l}2872(65.4) \\
962(21.9) \\
262(6.0) \\
156(3.6) \\
130(3.0)\end{array}$ & $\begin{array}{c}\text { Ref } \\
1.0(0.8,1.3) \mathrm{P}=0.72 \\
2.7(1.8,4.0) \mathrm{P}<0.0001 \\
1.5(0.9,2.5) \mathrm{P}=0.14 \\
2.2(1.3,3.7) \mathrm{P}=0.003\end{array}$ & $\begin{array}{c}\text { Ref } \\
1.0(0.8,1.3) \mathrm{P}=0.88 \\
3.1(2.1,4.8) \mathrm{P}<0.0001 \\
2.0(1.1,3.6) \mathrm{P}=0.02 \\
2.5(1.4,4.4) \mathrm{P}=0.002\end{array}$ \\
\hline $\begin{array}{l}\text { Marital status } \\
\text { Married - only wife } \\
\text { Married - first wife } \\
\text { Married - lower wife } \\
\text { Never married } \\
\text { Living together (LT) } \\
\text { Widowed/divorced/NLT }\end{array}$ & $\begin{array}{l}3001(68.3) \\
220(5.0) \\
374(8.5) \\
241(5.5) \\
245(5.6) \\
309(7.0)\end{array}$ & $\begin{array}{c}\text { Ref } \\
1.5(0.9,2.4) \mathrm{P}=0.08 \\
1.4(1.0,2.0) \mathrm{P}=0.07 \\
1.9(1.2,2.7) \mathrm{P}=0.002 \\
1.4(0.9,2.1) \mathrm{P}=0.13 \\
2.0(1.4,2.9) \mathrm{P}=0.0002\end{array}$ & $2.0(1.1,1.1) 1-0.004$ \\
\hline $\begin{array}{l}\text { Birthing location } \\
\text { Home } \\
\text { Public clinic } \\
\text { Private clinic }\end{array}$ & $\begin{array}{l}2445(55.7) \\
1440(32.8) \\
497(11.3)\end{array}$ & $\begin{array}{c}\text { Ref } \\
0.6(0.5,0.9) \mathrm{P} 0.0001 \\
0.6(0.4,0.8) \mathrm{P}=0.002\end{array}$ & $\begin{array}{c}\text { Ref } \\
0.7(0.5,0.9) \mathrm{P}=0.0031 \\
0.6(0.4,1.0) \mathrm{P}=0.03\end{array}$ \\
\hline
\end{tabular}

To be continued on next page 
Table 3. Continued from previous page.

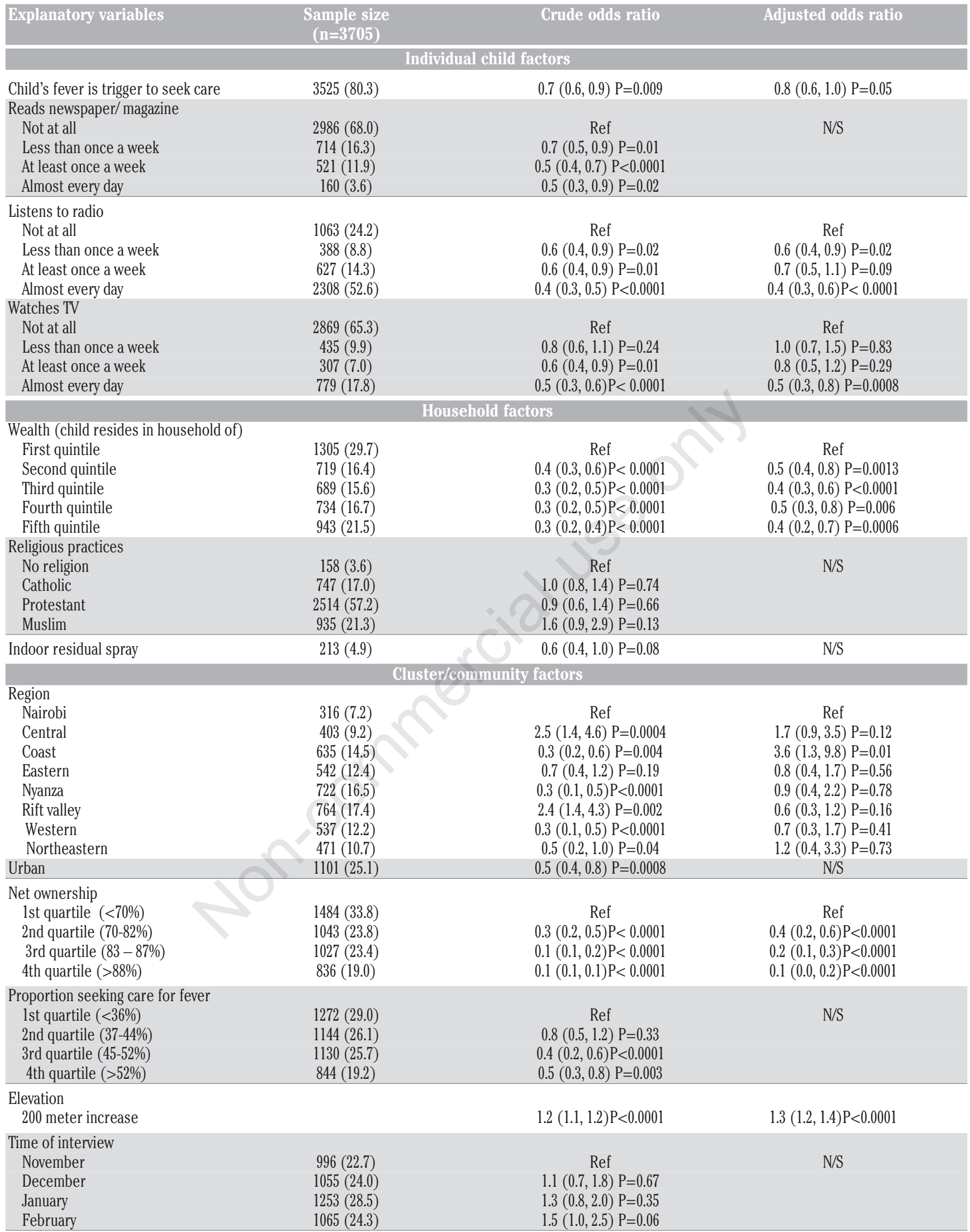


nets in the household are being used being four times more likely to be children of an extended family member. Surprisingly, daughters of the head of the household appear to have less access to bed nets than daughter-inlaws. It is possible that daughters are more likely to be unmarried if still residing at home and less likely to have a husband to advocate for their share of the resources. It is not surprising that the greatest association would be with the intra-household distribution of limited bed nets. Women, such as nieces, daughtersin-law, granddaughters who have less authority in the household may have less power to negotiate for limited household resources or less opportunity to earn their own.

\section{Maternal education}

Ownership of a bed net was associated with higher levels of education but there was no association between not using available bed nets in a household and education. We would have expected that more highly educated women would be using available nets to protect children from malaria given the strong correlation between malaria knowledge and education. ${ }^{30,31}$ Other studies have indicated a consistent relationship between sleeping under an ITN and the education level of the mother. ${ }^{24,29}$ We examined the data for interaction between variables that might approximate malaria risk (elevation) and education level but these were not significant.

\section{Bed net use by head of household}

Children who slept without a bed net when bed nets were available in the household were nearly 30 times more likely to have a head of household who also did not sleep under a bed net. This was not the case with intra-household access. This demonstrates that bed net use in these households is likely not prioritized or valued. Targeting these heads of household will likely prove critical in improving overall bed net compliance.

\section{Household wealth}

Economic inequity persists in net ownership as children sleeping in households without bed nets were more likely to be in the lowest wealth quintile. This indicates that either there is holdover in the inequity in bed net distribution prior to free distribution in 2006, or current distribution avenues may not be reaching households in the lower socioeconomic strata. The primary route of distribution of LLIN in Kenya has been through health clinics during antenatal visits. While free distribution may reduce inequity, ${ }^{14}$ it may not eliminate it. The cost of travel to the clinic and time spent away from household duties may limit households with the lowest level of wealth access to freely distributed nets. ${ }^{32,33}$ Supporting this hypothesis is the relationship between place of delivery and bed net ownership. Children of women who gave birth at a public or private clinic were more likely to own a bed net. This is not surprising given that distribution at antenatal clinics has successfully improved ITN ownership in other settings. ${ }^{34}$ Urban children were also less likely to live in households without bed nets. This is probably related to the greater access to bed nets in commercial areas. Risk of malaria, however, is much higher in rural areas. Reaching all rural communities is a formidable challenge that obviously still has to be overcome.

\section{Risk perception}

While not directly measured, there is some evidence that level of transmission and, perhaps, risk perception of malaria play a role in the ownership as well as use of bed nets. Children whose mothers were more likely to seek care if their child had a fever were more likely to own bed nets. Perhaps these mothers perceive malaria, the most recognized cause of fever in Kenya, as a serious health threat. It may also represent a broader acceptance of the biomedical model of disease with those more likely to use bed nets also being more likely to seek medical care when a child is ill. Children sleeping in households without a bed net or in households where available bed nets were not used were more likely to reside at higher elevations. It is well established that malaria risk in East Africa decreases at higher altitudes ${ }^{35,36}$ and there may be less concern about malaria as a serious health threat in these regions.

In general, intra-household bed net use (those children who slept without a bed net because all of them were being used) was not associated with community level factors. As the internal distribution of bed nets is likely about family decisions regarding priority household members, it is not surprising that the associations are dominated by internal factors within the household.

There are several notable limitations to this analysis, which are primarily related to using data that were not collected with the intention of examining factors related to bed net ownership and use. While the DHS survey is a comprehensive and representative country-wide survey that includes detailed information on the availability of bed nets, it lacks direct questions about malaria knowledge and attitudes. This requires assumptions to be made about the underlying reasons for many of the associations noted in this study.

\section{Conclusions}

Further research is needed to examine directly factors related to these three non-use categories. It appears that the primary drivers of bed net ownership at the household level differ from factors determining how bed nets are distributed in the household, as well as whether or not available bed nets are being used. Intra-household distribution and ownership may be improved with greater equitable distribution of bed nets and the change to universal coverage. Non-use of bed nets, however, will require more research, both qualitative and quantitative, to determine strategies that will improve their use.

\section{References}

1. Lengeler C. Insecticide-treated bed nets and curtains for preventing malaria. Cochrane Database Syst Rev 2004;2: CD000363.

2. McElroy PD, et al. All-cause mortality among young children in western Kenya. VI: the Asembo Bay Cohort Project. Am J Trop Med Hyg 2001;64:18-27.

3. Gratz NG. Emerging and resurging vectorborne diseases. Annu Rev Entomol 1999;44:51-75.

4. Sharma VP. Re-emergence of malaria in India. Indian J Med Res 1996;103:26-45.

5. Garcia-Basteiro AL, et al., Determinants of bed net use in children under five and household bed net ownership on Bioko Island, Equatorial Guinea. Malaria J 2011;10:179.

6. Malaria RB. Global Malaria Action Plan. 2008.

7. Division of Malaria Control,National Malaria Strategy 2009 - 2017. Kenyan Ministry of Public Health and Sanitation: Nairobi, Kenya, 2009.

8. Guyatt HL, et al. Free bed nets to pregnant women through antenatal clinics in Kenya: a cheap, simple and equitable approach to delivery. Trop Med Int Health 2002;7:409-20.

9. Guyatt H, Ochola S. Use of bed nets given free to pregnant women in Kenya. Lancet 2003;362:1549-50.

10. Kenyan National Bureau of Statistics and MEASURE DHS ICF Macro, Kenya: DHS, 2008-09 Final Report. 2010: Nairobi, Kenya and Calverton, MD, USA.

11. Agha $\mathrm{S}$, et al. The impact of a hybrid social marketing intervention on inequities in access, ownership and use of insecticidetreated nets. Malaria Journal 2007;6:13.

12. Astatkie A, Feleke A. Utilization of insecticide treated nets in Arbaminch Town and the malarious villages of Arbaminch Zuria District, Southern Ethiopia. Ethiopian Journal of Health Development 2010;24:153.

13. Matovu F, et al. How equitable is bed net 
ownership and utilisation in Tanzania? A practical application of the principles of horizontal and vertical equity. Malaria Journal, 2009;8:29.

14. Noor AM, et al. Increasing coverage and decreasing inequity in insecticide-treated bed net use among rural Kenyan children. Plos Medicine 2007;4:1341-8.

15. Noor AM, et al. Wealth, mother's education and physical access as determinants of retail sector net use in rural Kenya. Malaria Journal 2006;5:5.

16. Oresanya OB, Hoshen M, Sofola OT. Utilization of insecticide-treated nets by under-five children in Nigeria: Assessing progress towards the Abuja targets. Malaria Journal 2008;7:145.

17. Babu BV, et al. Personal-protection measures against mosquitoes: a study of practices and costs in a district, in the Indian state of Orissa, where malaria and lymphatic filariasis are co-endemic. Annals of Tropical Medicine and Parasitology 2007;101:601-9.

18. Hawley WA, et al. Community-wide effects of permethrin-treated bed nets on child mortality and malaria morbidity in western Kenya. American Journal of Tropical Medicine and Hygiene 2003;68:121-7.

19. Hii JLK, et al. Area effects of bed net use in a malaria-endemic area in Papua New Guinea. Transactions of the Royal Society of Tropical Medicine and Hygiene 2001;95:7-13.

20. Gosoniu L, et al. Spatial effects of mosquito bed nets on child mortality. BMC Public Health 2008;8:356.

21. Pulford J, et al. Reported reasons for not using a mosquito net when one is available: a review of the published literature. Malaria Journal 2011;10:83.

22. Atkinson JA, et al. A qualitative study on the acceptability and preference of three types of long-lasting insecticide-treated bed nets in Solomon Islands: implications for malaria elimination. Malaria Journal 2009;8:265.

23. Baume CA, Reithinger R, Woldehanna S. Factors associated with use and non-use of mosquito nets owned in Oromia and Amhara Regional States, Ethiopia. Malaria Journal 2009;8:265.

24. Belay M, Deressa W. Use of insecticide treated nets by pregnant women and associated factors in a pre-dominantly rural population in northern Ethiopia. Tropical Medicine \& International Health 2008;13:1303-13.

25. Ng'ang'a PN, et al. Malaria vector control practices in an irrigated rice agro-ecosystem in central Kenya and implications for malaria control. Malaria Journal 2008;7:146.

26. Atkinson JAM, et al. Community participation for malaria elimination in Tafea Province, Vanuatu: Part I. Maintaining motivation for prevention practices in the context of disappearing disease. Malaria Journal 2010;9:46-56.

27. Chuma J, et al. Towards achieving Abuja targets: identifying and addressing barriers to access and use of insecticides treated nets among the poorest populations in Kenya. Bmc Public Health 2010;10137.

28. Zhou GF, et al. Community-wide benefits of targeted indoor residual spray for malar- ia control in the Western Kenya Highland. Malaria Journal 2010;9:67.

29. Ng'ang'a PN, et al. Bed net use and associated factors in a rice farming community in Central Kenya. Malaria Journal 2009;8:64-71.

30. Daboer J, et al. Knowledge and treatment practices of malaria among mothers and caregivers of children in an urban slum in Jos, Nigeria. Niger J Med 2010;19:184-7.

31. Njoroge F, et al. Use of insecticide treated bed nets among pregnant women in Kilifi District, Kenya. East African Medical Journal 2009;86:314-22.

32. Mulligan JA, Yukich J, Hanson K. Costs and effects of the Tanzanian national voucher scheme for insecticide-treated nets. Malaria Journal 2008;7:32.

33. Onwujekwe 0, Hanson K, Fox-Rushby JA. Who buys insecticide-treated nets? Implications for increasing coverage in Nigeria. Health Policy and Planning 2003;18:279-89.

34. Muller 0, et al. Distribution Systems of Insecticide-Treated Bed Nets for Malaria Control in Rural Burkina Faso: ClusterRandomized Controlled Trial. Plos One 2008;3:e3182.

35. Bodker, R., et al., Relationship between altitude and intensity of malaria transmission in the Usambara Mountains, Tanzania. J Med Entomol 2003;40:706-17.

36. Akhwale WS, et al. Anemia and malaria at different altitudes in the western highlands of Kenya. Acta Tropica 2004;91:16775 . 